\title{
Investigation of the Extent of Wear Metals in Five Different Lubricating Oils Before and After Exposure to Engine Stress
}

\author{
Nasiru, Y. ${ }^{1}$, Muhammad A.B ${ }^{2}$, Bagudo B.U $\mathrm{U}^{2}$ Alhassan, $\mathrm{M}^{3}$ Sulaiman, M. $^{3}$ and Sahabi Y.M ${ }^{3}$ \\ ${ }^{1}$ Department of Chemistry, Sokoto State University, Sokoto P.M.B 2134, Sokoto State, Nigeria. \\ ${ }^{2}$ Department of Chemistry, Usmanu Danfodiyo University, Sokoto, Nigeria \\ ${ }^{3}$ Department of Chemistry, Sokoto State University, Sokoto, Nigeria
}

\begin{abstract}
Five different brands of Lubricating oils were used in five different vehicles viz: Toyota Carina II, Toyota 1992 (First lady), Golf 1990 Model, Honda 1996 Model and Mercedes Benz 190 Model respectively. The Ash method was adopted for digestion of samples followed by dissolution of samples with $5 \mathrm{~cm}^{3}$ of $0.1 \mathrm{M} \mathrm{HCl}$ acid, the digested samples was subjected to Atomic Absorption Spectroscopy. A selected wear metal concentrations determined for fresh lubricating oil, has a mean value between 0.36 to 5.86 for Al, 0.46 to 7.87 for $\mathrm{Cr}, 0.256$ to 0.913 for $\mathrm{Cd}, 1.337$ to 4.033 for $\mathrm{Cu}, 4.04$ to $31 \mathrm{for} \mathrm{Pb}, 0.75$ to 3.2 for Fe and 0.76 to $36.4 \mathrm{mg} / \mathrm{kg}$ for Mn. While their used oil wear metal concentration were in the range of 8.83 to 16.833 for Al, 7.03 to 45.5 for $\mathrm{Cr}, 1.64$ to 22.0 for $\mathrm{Cd}, 3.35$ to 16.27 for $\mathrm{Cu}, 27.8$ to 151.3 for $\mathrm{Pb}, 3.707$ to $9.73 \mathrm{for} \mathrm{Fe}$ and 13.07 to 45.10 $\mathrm{mg} / \mathrm{kg}$ for Mn. For the same wear metals. However the highest concentration of wear metal, was observed in Honda (1996 Model) while the information about wear metals concentration will be helpful in monitoring and maintaining vehicles engine
\end{abstract}

Keywords: Lubricating oils, wear metals, multigrade

\section{Introduction}

Engine oil quality monitoring has attracted considerable interest over the years since lubrication is a critical factor for the performance and longevity of automobile and industrial engines. Lubricating oils are complex composite mixture of hydrocarbons blended with chemical enhancers known as additives designed to operate under hostile environment. Their prime function is to provide a hydrodynamic lubrication on the surface onto which they are dispersed (Ronald at el, 2015). A usual practice in engine maintenance is the determination of the contents of certain heavy metals in the used lubricant oil, traces of wear metals in used lubricant may vary in origin and its concentration value. These wear metals concentration obtained from the used lube analyses provides vital information regarding the cause and level of deterioration existed and progressed in operating mechanical component. The concentration of metals in lubricating oil increase with automobile operating time and its amount is dependent on fuel type and the mechanical condition of the engine. (Mohamed at el, 2014). North American vehicles owner's manuals indicated that under most driving conditions other than freeway service, $12000 \mathrm{~km}$ was a recommended North American oil-change interval for freeway or longer distance service (G.E. Totten , 2006). In Turkey, investigation has shown that oil drain periods are between 3000 and $5000 \mathrm{~km}$, which is short when compared to other European countries. It has been noticed that in some Arabian countries, the common travelled distance for the lubricating oil is between $2000 \mathrm{~km}$ and $3000 \mathrm{~km}$. It was observed that there is no guideline for the appropriate travelled distance and that is due to various reasons such as the engine state of the engine, filter type, climate and the design of the road passed through. In developing countries, like Nigeria, the travelling distance for lubricating oils is between $1800 \mathrm{~km}$ to $3000 \mathrm{~km}$ or higher than that depending on whether the car engine is commercial, private or otherwise. It has been noticed that there is no guideline governing the travelled distance in Nigeria due to various policy

The oil sample itself presents handling difficulties, as it may occur in the form of an extremely viscous liquid. A number of analytical procedures have been described. Most of which are based on ashing or dilution of the oil sample with an organic solvent, (Zie,sba, 1998, Meckenzie, 1981), Determined 12 element (Al, Cr, Cu, $\mathrm{Fe}, \mathrm{Mg}, \mathrm{Na}, \mathrm{Ni}, \mathrm{Pb}, \mathrm{Si}, \mathrm{Sn}, \mathrm{Zn}$ and Ti) using Flame Atomic Absorption Spectroscopy. After direct aspiration of an oil sample diluted in an organic solvent.

Vigler and Gaylor (1994) determined 25 elements in petroleum products after ashing sample in the presence of sulphuric acid. Barboot et al (1990) determined $\mathrm{Cr}, \mathrm{Fe}, \mathrm{Mg}$ and $\mathrm{Pb}$ in used lubricating oils using Flame Atomic Absorption Spectroscopy after three types of sample preparation: direct dilution with an organic solvent, dry ashing-acid dissolution and dry ashing in the presence of a porous inert material (silica gel). They explained that direct dilution could be applied to highly volatile metals such as $\mathrm{Pb}$ which could be lost during heating. Dry ashing was proved useful. For most metals, provided that the rate of heating was slow, the presence of silica gel prevented sputtering and volatilization of the sample.Nwosu et al. (2008) determined wear metals 
content in virgin and used lubricating oils were by ash method of analysis was adopted, in which sixteen element were determined

\section{Sample Collection}

Twenty (20) samples of used and unused lubricating oil were collected from two filling stations in Sokoto and one from vendor in Sokoto metropolis, the manufacturing companies of these lubricating oils are Total lubricant company Nig Ltd, Lubcon oil Nig Ltd and Oando Co Ltd, while the names and type are Total Quartz 5000sl,quartz 2500 Lubcon adriline, premium quality motor oil SAE 50 Api, Oando Motor oil SAE40 and SuperXV premium their corresponding used lubricating oil were collected from different vehicles at the point of oil change in mechanic workshops in Sokoto and stored in a clean dry 5 liters containers and the sample were designated as used lubricant. The same fresh lubricants were used in car engines to generate used lubricating oil that were used to carry out this analysis

\section{Experimental Design}

Five brands of lubricating oils were used in five different vehicles namely Toyota Carina II, Mercedes Benz, Golf 1990 model, Honda 1996 and Toyota 1992 model (First lady) were used to generate used lubricating oils. Fresh samples were obtained each before it was put into the car engines; each car was run three times with the lubricating oils.

\section{Sampling Procedure}

The fresh lubricating oil samples used in this research were collected directly from seal gallons bought from filling stations, used lubricating oils were collected at the point at which the lubricant was changed. The samples were taken when the engine is warm (normal running temperature) and from the same location within the engine in order to obtain a representative sample. All the samples were stored at room temperature.

\section{Experimental}

Dry digestion method of Ashing techniques were used, $5 \mathrm{~g}$ each of the samples were weighed in a clean, dry crucible and heated in muffle furnace gradually up to $525^{\circ} \mathrm{C}$ for about 1 hour. Smoke, irritating smell was also observed, the oil burnt completely in to ash. It was then cooled in dessicator and then weighed (Bercowitz, 1979). Followed by dissolution of samples with $5 \mathrm{~cm}^{3}$ of $0.1 \mathrm{M} \mathrm{HCl}$ acid, the digested samples were subjected to Atomic Absorption Spectroscopy. The ashing technique was chosen to destroy the organic matrix because it is more economical and to avoid the organic vapors. All reagents used were of analytical-reagent grade.

\section{Result And Discussion}

Tables 1, 2 and 3 shows the distance covered by each car engine under investigation, concentration of wear metals in $\mathrm{mg} / \mathrm{kg}$ and the statistical value obtained, in all, there is an increase in concentration of $\mathrm{Al}, \mathrm{Cr}, \mathrm{Cd}$, $\mathrm{Cu}, \mathrm{Pb}$ and $\mathrm{Fe}$ after being exposes to engine stress. For fresh lubricating oils the highest concentration of $\mathrm{Al}, \mathrm{Cr}$, $\mathrm{Cu}, \mathrm{Pb}, \mathrm{Fe}$ and $\mathrm{Mn}$ was observed in Honda 5.85 \pm 2.56, 7.87 \pm 5.62, $4.03 \pm 1.258,31.0 \pm 12.24,3.2 \pm 2.0$ and $36.43 \pm 15.40 \mathrm{mg} / \mathrm{kg}$ respectively, the concentration values obtained in this research are lower than the values reported by Behnman et al, (2012) who reported the concentration $\mathrm{Cr}, \mathrm{Cd}, \mathrm{Cu}, \mathrm{Pb}$, and $\mathrm{Fe}$ with the value of $10.68 \pm 3.420,1.6870 \pm 0.326,6.549 \pm 0.152,81.15 \pm 2.24$ and $10.3 \pm 7.05 \mathrm{mg} / \mathrm{kg}$ respectively, but higher than what is reported by Muhammad et al, (2014) and Marine Beauvir, (2013). Whose reported the concentration of $\mathrm{Al}, \mathrm{Cr}, \mathrm{Cd}, \mathrm{Cu}, \mathrm{Pb}, \mathrm{Fe}$ and $\mathrm{Mn}$ with the values of $0.09,0.12,0.15,0.58,16,2.76$ and 0.21 $\mathrm{mg} / \mathrm{kg}$ in fresh lubricating due to differences in base oils, addatives formulation and the origin of crude oil itself, for $\mathrm{Cd}$ the highest concentration was observed in Mercedes benz with the mean value of $1.343 \pm 0.329 \mathrm{mg} / \mathrm{kg}$ and the least concentration in fresh lubricating oil was noticed in for $\mathrm{Cr}, \mathrm{Cd}, \mathrm{Cu}$ and $\mathrm{Pb}$, in Toyota Carina II with mean value of $0.460 \pm 0.433,0.256 \pm 0.1436,1.337 \pm 0.935$ and $4.04 \pm 2.41 \mathrm{mg} / \mathrm{kg}$ respectively and for Al and Fe Golf has the least concentration of $0.363 \pm 0.445$ and $0.757 \pm 0.512 \mathrm{mg} / \mathrm{kg}$ respectively. The higher concentration observed in Honda may be connected to the fact that the oil used in Honda may be multigrade (Okeola, et al, 2011)

For used lubricating oil the increase in concentration of wear metals after being exposes to engine stress was observed in table 1.0, the wear metals increase with distance covered by each vehicles except Manganese which decrease with increase in distance covered is a clear indication that Mn was consumed in the process as an additive, as such appropriate portion need to be added to the lubricating oil Nwosu et al, (2008)

The concentration of $\mathrm{Al}, \mathrm{Cr}, \mathrm{Cd}, \mathrm{Pb}$ and $\mathrm{Mn}$ are lower than the concentration reported by Marine Beauvir, (2013) and David Hilligos, (2012) who reported the concentration as 0.05 to 6.0, 3.0 to 2.54, 0.27, $12.1 \mathrm{mg} / \mathrm{kg}$ respectively Nwosu et al. (2008) reported on $\mathrm{Pb}$ with the value of $601 \mathrm{and} 810 \mathrm{mg} / \mathrm{kg}$.but for Mn they reported lower value of 0.63 and $12.02 \mathrm{mg} / \mathrm{kg}$, there is also increase in concentration of Mn not decrease, this 
may be connected with the fact that here in Nigeria the car's used for day to day activities are mostly second hand or fairly used car's (tokumbo car's)

In all the vehicles under investigation Honda has the highest concentration of $\mathrm{Al}, \mathrm{Cr}, \mathrm{Pb}$ and $\mathrm{Fe}$ in used lubricating oil with the mean value of $16.833 \pm 1.504,45.5 \pm 34.0,151.3 \pm 150.8$ and $7.95 \pm 3.97 \mathrm{mg} / \mathrm{kg}$, the Honda has covered a long distance which lead to the wearing out of these metals from the engine component, the concentration of Cd is observed to be higher in TC II with the mean value of $22.0 \pm 36.2 \mathrm{mg} / \mathrm{kg}$.

Table 3 Results of effect of car type and exposure time on the wear metals concentration of engine oil, except for $\mathrm{Al}$ and $\mathrm{Mn}$ are lower than $0.05 \mathrm{p}$-value and $\mathrm{Cr}, \mathrm{Cd}, \mathrm{Pb}, \mathrm{Cu}$ and $\mathrm{Fe}$ are greater than probabilities value of 0.05 , also for $\mathrm{Cr}$ and $\mathrm{Cd}$ there is no significant difference between the type of car used and the exposure to engine stress, while for $\mathrm{Cu}, \mathrm{Pb}, \mathrm{Fe}$ and $\mathrm{Mn}$ there is significant difference between the car type and the exposure of lubricating oil to engine stress.

\section{Conclusion}

The investigation of wear metals in used automobile vehicle engine is vital in determining the wear and tear occurring during day to day use. It also helps in establishing the appropriate method for enhancing the quality of the lubricating oils and increasing the performance of engines.

\section{Reference}

[1]. Barbooti, M.M. Zaki, N.S,. Baha-Udolin(1990) Use of silica gel in the preparation of used lubricating oil samples for the determination of wear metals by flame AAS, Analyst $115 \quad$ Pp 1059-1061

[2]. Behnam Rahimi, Abolfazl Semnani, Alireza Nezamzade Ejhieh, Hamid Shakoori Langeroodi and Massoud Hakim Davood (2012) Global Journal of Science Frontier research ChemistryVolume 12 (2) Type : Double Blind Peer Reviewed International research Journal Publisher:Global Journals Inc. (USA)

[3]. Bercowitz, N (1979) an introduction to coal technology, Academics press inc NY p3-100

[4]. Cassap M (2008) the analysis of used lubrication oil by inductively couple plasma spectrometry predictive maintenance. Spectroscopic Europe 20 (1) 17-20

[5]. David Halligos (2012) Analysis of Wear Metals and Additive Package Elements in New andused Oil Using the Optima 8300 ICPOES with Flat Plate Plasma Technology perkinElmer, Inc.940 Winter Street Waltham, MA 02451 USA

[6]. Marine Beauvir (2013) Lubricating oil analysis according to ASTM D5185 using the Thermo P7400 ICP-OES Thermo Fisher Scientific, Cambridge, UK retrieve 19/6/2016 from www.thermoscientific.com

[7]. McKenzie, T (1981) Atomic Absorption Spectrophotometry for the Analysis of Wear Metals in Oil Samples, varian instrument at work,varian atomic absorption AA-10 pp 2-5

[8]. Mohamed S. Al-Nozili, Fathy A. Abeed, Majed. M. Ahmed (2014) Studying the Changes of in Lubricating Oil with their Travelled Distance: Part II oil Validity. International Journal of Emerging Technology and Advanced engineering Website: www.ijetae.com Volume 4( 10)

[9]. Nwosu, F.O, F.O, Iromidayo, B.Oi, Oyebode K.A and Leke, L (2008) Comparative Investigation Wear Metal in Virgin and Used Lubricating oils, Terrsterial and Aquatic Environment Toxicology 2(1). pp. 34-42

[10]. Okeola F.O., Odebunmi E.O. and Aremu J. (2011) Comparative Assessment of Physicochemical Properties of Common Automobile Consumable Oils, American Eurasian Network for Scientific Information, Advances in Environmental Biology, 5(1), pp 1-4

[11]. Ronald Nguele, Hikmat Said Al-Salim Kyuro Sasaki (2015) Oil Condition Monitoring Degradation Mechanisms and Additive Depletion Journal of Multidisciplinary Engineering Science and Technology Vol. 2 (3)

[12]. Vigler,M.S and. Gaylor, F.V (1994)Trace metals analysis in petroleum products by AAS, Applied Spectroscopy 8(1974) 342344.

[13]. Zie ba, J.P (1998) Examination of used motor oils by flame AAS for criminalistic purposes: a diagnostic study, Forensic Science International 91 pp171-179

Table 1: the sources of the used engine oil and the approximate distance covered by each vehicle

\begin{tabular}{|l|l|l|l|}
\hline Sample I.D & Kilometres Covered/ Duration & Car Model & Oil Type \\
\hline $\mathrm{H}_{1.1}$ & 2453 & Honda Hala 96 Model & Quartz 5000sl \\
\hline $\mathrm{H}_{1.2}$ & 2013 & Honda Hala 96 Model & Quartz 5000s1 \\
\hline $\mathrm{H}_{1.3}$ & 1828 & Honda Hala 96 Model & Quartz 5000sl \\
\hline $\mathrm{M}_{1.1}$ & 1576 & Mercedes 190 & Lubcon Adrilne \\
\hline $\mathrm{M}_{1.2}$ & 1935 & Mercedes 190 & Lubcon Adrilne \\
\hline $\mathrm{M}_{1.3}$ & 1654.76 & Mercedes 190 & Lubcon Adrilne \\
\hline $\mathrm{F}_{1.1}$ & 2 Months & Toyota 92 & Quartz 2500s1 \\
\hline $\mathrm{F}_{1.2}$ & 2 Months & Toyota 92 & Quartz 2500s1 \\
\hline $\mathrm{F}_{1.3}$ & 2 Months & Toyota 92 & Quartz 2500s1 \\
\hline $\mathrm{G}_{1.1}$ & 1523 & Golf 1990 Series & Oando \\
\hline $\mathrm{G}_{1.2}$ & 1645 & Golf 1990 Series & Oando \\
\hline $\mathrm{G}_{1.3}$ & 1348 & Golf 1990 Series & Oando \\
\hline $\mathrm{C}_{1.1}$ & 2 Months & Toyota Carina II & Super XV \\
\hline $\mathrm{C}_{1.2}$ & 2 Months & Toyota Carina II & Super XV \\
\hline $\mathrm{C}_{1.3}$ & 2 Months & Toyota Carina II & Super XV \\
\hline
\end{tabular}

H, C, M, G and F= Honda, Carina II, Mercedes Benz, Golf and Toyota first lady: 1.1, 1.2 and 1.3 stand for fresh lubricating oil 
Table 2: Wear metals content in different car engine before being expose to engine stress and after being expose to engine stress

\begin{tabular}{|c|c|c|c|c|c|c|}
\hline & & & \multicolumn{3}{|c|}{ Concentration in $\mathrm{mg} / \mathrm{kg}$} & \multirow[b]{2}{*}{ Honda } \\
\hline \multirow[t]{2}{*}{ Metals } & \multirow[t]{2}{*}{ Time } & MB 1990 & TC II & T 1992 & Golf1990 & \\
\hline & & & \multicolumn{3}{|l|}{ Mean value } & \\
\hline \multirow[t]{2}{*}{$\mathrm{Al}$} & $\mathbf{B}$ & \pm 3.45 & $4.49 \pm 6.03$ & $4.737 \pm 1.599$ & $0.363 \pm 0.445$ & \pm 2.56 \\
\hline & $\mathbf{A}$ & $15.517 \pm 1.588$ & $8.83 \pm 3.46$ & $7.30 \pm 2.74$ & $9.49 \pm 2.92$ & $16.833 \pm 1.504$ \\
\hline \multirow[t]{2}{*}{$\mathrm{Cr}$} & $\mathbf{B}$ & $3.957 \pm 1.374$ & $0.460 \pm 0.433$ & $2.797 \pm 1.649$ & $1.21 \pm 1.90$ & \pm 5.62 \\
\hline & $\mathbf{A}$ & $14.03 \pm 8.21$ & $7.033 \pm 0.709$ & $7.70 \pm 3.35$ & $12.48 \pm 11.06$ & \pm 34.0 \\
\hline \multirow[t]{2}{*}{$\mathrm{Cd}$} & B & $1.343 \pm 0.329$ & $0.2567 \pm 0.1436$ & $0.433 \pm 0.421$ & $0.307 \pm 0.339$ & $0.913 \pm 0.257$ \\
\hline & $\mathbf{A}$ & \pm 10.44 & $22.0 \pm 36.2$ & $1.667 \pm 0.208$ & $1.750 \pm 0.530$ & $1.640 \pm 0.515$ \\
\hline \multirow[t]{2}{*}{$\mathrm{Cu}$} & $\mathbf{B}$ & $2.893 \pm 0.696$ & $1.337 \pm 0.935$ & $1.553 \pm 1.600$ & $3.367 \pm 0.862$ & $4.033 \pm 1.258$ \\
\hline & $\mathbf{A}$ & $16.27 \pm 12.12$ & \pm 2.29 & $3.353 \pm 0.508$ & $3.847 \pm 1.184$ & $10.25 \pm 4.45$ \\
\hline \multirow[t]{2}{*}{$\mathrm{Pb}$} & B & $5.87 \pm 3.69$ & $4.04 \pm 2.41$ & $7.60 \pm 6.77$ & $10.14 \pm 5.80$ & \pm 12.24 \\
\hline & $\mathbf{A}$ & \pm 28.5 & \pm 19.9 & $44.3 \pm 32.6$ & $32.20 \pm 5.53$ & $151.3 \pm 150.8$ \\
\hline \multirow[t]{2}{*}{$\mathrm{Fe}$} & B & $1.62 \pm 2.67$ & $1.0967 \pm 0.1686$ & $0.970 \pm 0.221$ & $0.757 \pm 0.512$ & \pm 2.0 \\
\hline & $\mathbf{A}$ & \pm 5.01 & $9.73 \pm 2.49$ & $3.707 \pm 1.288$ & $7.06 \pm 2.25$ & \pm 3.97 \\
\hline \multirow[t]{2}{*}{$\mathrm{Mn}$} & B & $30.68 \pm 14.09$ & $24.83 \pm 8.13$ & $0.760 \pm 0.612$ & $4.96 \pm 5.71$ & $36.43 \pm 15.40$ \\
\hline & $\mathbf{A}$ & $45.10 \pm 8.57$ & $13.07 \pm 4.24$ & $14.53 \pm 14.94$ & $21.70 \pm 9.45$ & $23.14 \pm 6.68$ \\
\hline
\end{tabular}

Source: Data collected from the Researcher

$A=$ after being exposes to engine stress MB $190=$ Mercedes Benz 190 Model Honda Hala 1996 Model
B=before exposure to engine stress T $1992=$ Toyota 1992Model TC II= Toyota Carina II T 1992 Golf 1990 Model

Table 3: Results of effect of car type and exposure time on the Wear metals concentration of engine oil.

\begin{tabular}{|l|l|l|}
\hline \multicolumn{3}{|c|}{$\boldsymbol{p}$-value (at $\boldsymbol{\alpha}=\mathbf{0 . 0 5})$} \\
\hline $\mathrm{Wear}$ metal type & Car type & Time \\
\hline $\mathrm{Al}$ & $0.007^{*}$ & $0.000^{*}$ \\
\hline $\mathrm{Cr}$ & $0.251+$ & $0.173+$ \\
\hline $\mathrm{Cd}$ & $0.534+$ & $0.156+$ \\
\hline $\mathrm{Cu}$ & $0.057+$ & $0.001^{*}$ \\
\hline $\mathrm{Pb}$ & $0.085+$ & $0.024^{*}$ \\
\hline $\mathrm{Fe}$ & $0.212+$ & $0.000^{*}$ \\
\hline $\mathrm{Mn}$ & $0.000^{*}$ & $0.269+$ \\
\hline
\end{tabular}

+ indicate where there is no significant difference between fresh and used lubricating oil in different vehicles, while * means value are significant difference between their time. 